\title{
Yerel Özerklik Bağlamında Belediyelerin Denetimi: İtalya ve Türkiye Örneği
}

\author{
Control of Municipalities in Local Autonomy Context: The Case of \\ Italy and Turkey
}

Hülya KÜÇÜK*

\section{Öz}

Denetim kavramının, yerel özerklikle ters orantılı olduğu yönünde tartışmalar bulunmaktadır. Yerel yönetimlerin üzerindeki denetim arttıkça yerel özerklik azalmakta, denetim azaldıkça yerel yönetimler daha geniş bir özerklikten yararlanmaktadır. Yerel yönetimlerin gerçek anlamda var olabilmesi için yerel yönetimleri Anayasa ile güvence altına almak ve vesayet denetiminin sınırlarını iyi bir şekilde belirlemek büyük önem taşımaktadır. Yerel yönetimlerin özerk olmaları görevlerini en iyi şekilde yerine getirebilmeleri açısından oldukça önemlidir. Yerel yönetimlerin özerkliği, kanunlarla belirlenen sınırlar çerçevesinde, kamu işlerinin önemli bir bölümü kendi sorumlulukları altında ve yerel nüfusun çıkarları doğrultusunda düzenleme ve yönetme hakkı ve imkânı anlamını taşımaktadır. Bu bağlamda yerel yönetimlerin kendi organlarıyla kendileri ile ilgili konularda merkezin baskısı ve yönlendirmesi olmadan kendi imkânlarıyla karar alabilmesi özerklik için önemli bir yere sahiptir. İtalya ve Türkiye'de yerel yönetimler Anayasal olarak güvence altına almakta, merkezi yönetim tarafından yerel yönetimler üzerinde idari vesayet denetimi uygulanmaktadır.

Bu çalışmanın amacı, İtalyảnın merkezi yönetiminin belediye yönetimi üzerindeki denetimiyle, Türkiye’deki belediyelerin denetimini karşılaştırma yaparak incelemektir. İki ülkenin denetim açısından benzer ve farklı yönleri ele alınarak, Türkiye'deki denetim sistemine ışık tutabilmesi amaçlanmıştır. Çalışmada, yerel özerklik, mali özerklik ve idari vesayet kavramlarına açıllık getirilerek yerel özerklikle denetim arasındaki ilişki Avrupa Yerel Yönetimler Özerklik Şartı bağlamında ele alınıp kavramsal çerçeve oluşturulacaktır. İtalya ve Türkiye’nin belediye yönetim birimleri ayrıntılı bir șekilde ele alıncaktır. İki ülkenin belediye yönetimleri merkezi yönetimle olan ilişkisi idari vesayet denetimi üzerinden değerlendirilecektir.

Çalışmada elde edilen bulgulardan yola çıkarak, İtalya’nın üniter yapılı bir devlet olmasına rağmen merkezi yönetimin bölgesel yönetimleri yoğun bir şekilde denetlemediğini söylemek mümkündür. Bölgesel yönetimlerin ise, illeri ve belediyeleri hukuki açıdan denetlediği ve Avrupa Yerel Yönetimler Özerklik Şartı’nın denetimle ilgili maddesine uygun şekilde düzenlemeler yaptığı görülmektedir. Türkiye de üniter yapıya sahip bir ülkedir ve AYYÖŞ’ün denetimle ilgili maddesine çekince koymuştur. 2000’li yıllarda yaptığı reformlarla yerel yönetimlerin özerkliklerini genişlettiği görülse de yapılan son düzenlemeyle merkeziyetçi yapısını korumaya devam ettiği görülmektedir. İtalya ve Türkiye’nin Avrupa Yerel Yönetimler Özerklik Şartı bağlamında denetime olan yaklaşımları incelendiğinde Türkiye’nin uyguladığı denetimin İtalya’ya kıyasla Şarta pek de uygun olduğunu söylemek mümkün

* Doktora Öğrencisi, İstanbul Üniversitesi, Siyaset Bilimi ve Kamu Yönetimi Anabilim Dalı, hulya.kucuk@ogr.iu.edu.tr 
değildir. İtalya ve Türkiye yerel yönetimlerin özerkliği noktasında birbirinden farklılık göstermektedir. İtalyảnın yerel yönetimler üzerindeki denetim sınırları ve Avrupa Yerel Yönetimler Özerklik Şartı’na bakış açısı bağlamında Türkiye’ye örnek olabilecek özellikler barındırdığı söylenebilir.

Anahtar Kelimeler: Özerklik, Demokrasi, Denetim, İtalya, Türkiye

\begin{abstract}
There are arguments about the concept of control being inversely proportional to local autonomy. As the control over local governments increases, local autonomy decreases. As the control decreases, local governments benefit from a wider local autonomy. In order for local governments to exist in a real sense, it is important to secure them with the Constitution and to better define the boundaries of guardianship control. The autonomy of local governments is very important in terms of being able to perform their tasks in the best way. The autonomy of local governments means within the boundaries defined by the law having the organization and management right and possibility of a significant part of the public affairs under their responsibility and within the interests of the local people. In this context, local governments' being able to make decisions with their own bodies and opportunities about their own issues without the pressure and direction of the centre is highly significant for autonomy. Local governments in Italy and Turkey are secured constitutionally and administrative supervision over local governments is implemented by the central government.

The aim of the study is to compare Italy's central government control over the municipal administration and the control over the municipalities in Turkey. The control system in Turkey is aimed to be pointed out by considering the similar and different aspects of the two countries in terms of controlling. In the study, by clarifying the concept of local autonomy, financial autonomy, and administrative tutelage, the relationship between local autonomy and supervision will be dealt within the context of the European Local Governments Autonomy Charter and a conceptual framework will be established. The municipal government units of Italy and Turkey will be discussed in detail. The relationship of the municipalities of the two countries with the central government will be evaluated on the basis of the administrative tutelage supervision.

By looking at the findings of the study, it can be said that although Italy is a unitary state, the central government does not intensively monitor the regional administrations. It can be observed that the regional authorities regulate the cities and the municipalities from a legal side and in accordance with the audit-related point of the European Local Governments Autonomy Charter. Turkey is also a country with a unitary structure and has made reservations to European Local Governments Autonomy Charter's audit-related point. Although local governments have expanded their autonomy with the reforms made in the 2000s, it can be seen that with the last regulation its centralist structure has been maintained. When the approach of Italy and Turkey to the controlling within the context of European Local Governments Autonomy Charter is examined, it is not possible to say that the controls applied by Turkey is appropriate to the Charter when compared to Italy. Italy and Turkey are different from each other in terms of autonomy of local governments. Italy can be set as an example for Turkey in terms of its control boundaries over local government and approach to European Local Governments Autonomy Charter.
\end{abstract}

Keywords: Autonomy, Democracy, Control, Italy, Turkey.

\title{
Giriş
}

Yerel yönetimler, merkezi hükümetin hiyerarşik birimleri değildir Yerel yönetimler özerk kuruluşlardır, yani kanunlarla belirlenen sınırlar çerçevesinde, kamu işlerinin önemli bir bölümü kendi sorumlulukları altında ve yerel nüfusun çıkarları doğrultusunda düzenleme ve yönetme hakkı ve imkânın ve serbest karar alma organlarının bulunması, idari ve mali özerkliğe sahip 
olmaları anlamına gelmektedir. Yerel yönetimlerin özerkliği, bağımsızlık anlamına da gelmemekte ve yerel yönetimler merkezi yönetimler tarafından denetlenmektedir.

Türkiye’de ülkenin ulusal birliğinin bozulmaması için, yerel yönetimlerin özerkliğine pek sıcak bakılmamakta, yerel yönetimler kontrol altında tutulmaya çalışılmaktadır. Bugüne kadar yerel yönetimlere görev ve yetkiler verilirken genelde şüpheyle yaklaşılmış ve Avrupa Konseyi’nin çabaları sonucunda ortaya çıkan Avrupa Yerel Yönetimler Özerklik Şartı’nın tanımladığı özerk yerel yönetim kavramından oldukça uzak kalınmıştır. Yerel yönetimler üzerinde yapılan vesayet denetimin sınırı onların özerkliği açısından oldukça önemlidir. Çünkü vesayet ve özerklik kavramları birbirleriyle ters orantılıdır. Yani vesayet denetimi arttıkça yerel yönetimlerin özerkliği daralmakta, vesayet denetimi azaldıkça özerklik artmaktadır.

Yerel yönetimlerin gerçek anlamda var olabilmesi için yerel yönetimleri Anayasa ile güvence altına almak ve vesayet denetiminin sınırlarını iyi bir şekilde belirlemek büyükönem taşımaktadır. Üniter yapıya sahip olan İtalya ve Türkiye'nin Anayasalarında yerel yönetim birimleri tanımlanarak yasal olarak güvence altına alınmıştır.

1982 Anayasası’nın 127. maddesinde Türkiyede ki yerel yönetim birimleri il, belediye ve köy olarak sayılmaktadır ve mahalli idarelerin kuruluş ve görevleri ile yetkileri, yerinden yönetim ilkesine uygun olarak kanunla düzenlenir denmektedir (1982 Anayasası, md.127). İtalya’da ise, 1948 Anayasası'nın 114. maddesine göre, yerel yönetim birimleri bölgelere, illere ve komünlere ayrılmıştır (İtalyan Anayasası, md.114). Bu madde ile 1948 İtalyan Anayasası da yerel yönetimlerin varlığını anayasal güvence altına alarak korumuştur.

Dünyada birçok yerel yönetim sistemi bulunmaktadır. Bu sistemlerin içinde İtalya ve Türkiye, Hesse ve Sharpe'nin tipolojisi olan ve yerel yönetimleri Anayasal olarak güvence altına alan, merkezi yönetim tarafından yerel yönetimler üzerinde idari vesayet denetimi uygulanan "Franco" grubu kategorisini paylaşan ancak çalışmada da gösterileceği üzere idari vesayet denetimi bağlamında farklılıklarıyla çalışmanın konusu oluşturmaktadır (Çam, 2012, s.18-21).

Bu çalışmada İtalya ve Türkiye’deki belediye yönetimlerinin yapısı ele alınacak, yerel özerklik, mali özerklik ve idari vesayet denetimi kavramları tanımlanarak yerel yönetimlerle olan ilişkisi incelenecektir. Yerel özerklikle denetim arasındaki ilişki Avrupa Yerel Yönetimler Özerklik Şartı bağlamında ayrıntılı bir şekilde ele alınıp kavramsal çerçeve çizildikten sonra Türkiye ve İtalya’daki yerel yönetim birimi olan belediyelerin üzerindeki idari vesayet denetimi incelenecektir. İki ülkedeki belediye yapılanmaları üzerindeki idari vesayet denetimi karşılaştırılarak benzer ve farklı yönleri ortaya konulmaya çalışılacaktır.

\section{İtalya'da Belediye Yönetimi}

İtalyan Anayasası'nın 5.maddesi; “Tek ve bölünmez Cumhuriyet, yerel özerklikleri tanır ve güçlendirir; devlete bağlı hizmetlerde idari ademi merkeziyeti tam olarak uygular; kendi mevzuat, 
ilke ve yöntemleri özerklik ve yerinden yönetimin gerekliliklerine uyumlu hale getirir” şeklinde yerel özerkliklerin önemine yer vermiştir (1948 İtalyan Anayasası, md.5).

İtalyan Anayasanın 114. Maddesinde: "Cumhuriyet bölgelere, illere ve komünlere ayrılır. Komünler, iller, metropol kentler ve bölgeler Anayasada belirlenen ilkelere göre, kendilerine özgü tüzük, yetki ve sorumlulukları olan özerk kuruluşlardır” şeklinde yerel yönetimler tanımlanmıştır (İtalyan Anayasası, md. 114). Anayasada yer alan ilkelere göre bu yapılar kendi statüleri, yetkileri ve ayırt edilebilir işlevleri ile görece özerktir.

$\mathrm{Bu}$ çalışmada İtalya'daki yerel yönetim birimleri içinden belediyeler ele alınacağı için belediye yönetiminin yapısı ve organları ile ilgili bilgi verilecektir.

\section{Belediyelerin Görevleri}

İtalya'da belediyelerin tarihi, krallık anayasası dönemine kadar uzanmaktadır. Belediyelerin bugünkü sınırları 1861 yılında belirlenmiştir. 1948 İtalyan Anayasasına göre ise, belediyeler yasalarca belirlenen ilkeler çerçevesinde özerk yapıya sahip olan yerinden yönetim kuruluşlarıdır.

İtalyan Anayasası'nın 118.maddesinde;

"Katmanl yetki, ayırma ve orantılllik ilkesi uyarınca, uygulamada teklik sağlamak için, illere, metropol kentlere veya bölgeler veya Devlete atfedilmekdikçe, idari fonksiyonlar komünlere verilir. Komünler, il ve metropol kentler, kendi yetkileri doğrultusunda, kendi idari görevlerinin yanısira Devlet tarafindan veya bölgesel mevzuat tarafindan kendilerine verilen görevleri yürütür" (md.118) şeklinde ifade edilerek belediyelerin yetki alanının anayasal çerçevesi belirtilmiştir.

İtalyan yerel yönetim sistemi içerisinde belediyeler önemli bir yere sahiptir. Belediyeler önemli kamu hizmetlerini geniş çapta hizmetler vererek yerine getirirler (Dente, 1991, s.110).

Belediyelerin görevleri üç kategoride özetlenebilir: Sosyal hizmetler, ekonomik kalkınma hizmetleri ve düzenleme hizmetleri.

- Sosyal hizmetler; sağlık işleri, toplumsal yardım, halk konutları ve sınırlı eğitim hizmetlerinden oluşmaktadır (Toksöz vd., 2009, s.92).

- Ekonomik kalkınma hizmetleri; ticari faaliyetlerin denetimi, turizm ve tarımın geliştirilmesi gibi konuları içerir (Toksöz vd., 2009, s.93)

- Düzenleme hizmetleri; bayındırlık işleri, pazar ve fuar yerleri, fiziksel planlama, tarihsel anıtların korunması, yerel polis, kitle taşımacılı̆̆ı, kamusal altyapılar, afet kurtarma ve yardım işleri, dinlenme ve kültür tesisleri, okul, yol yapımı, bakım ve onarımı, nüfus ve seçim kütüklerinin tutulması, harç ve vergilerin toplanmasıdır (Geray, 1997, s.55).

Belediyeler, diğer yerel yönetim birimlerinin görev alanı içerisinde olmayan ekonomik kalkınma, alan kullanımı ve düzenlenmesi, sosyal hizmetler konusundaki idari görevleri belediye sınırları 
içerisinde yerine getirirler. Belediyelerin yerine getirdikleri en önemli kamu hizmetleri; eğitim ve sağlıktır (Dente, 1991, s.110).

Belediyenin diğer görevleri ise; askerlik hizmetlerini, nüfus kayıtları ve seçim hizmetlerini düzenlemektir ve bu görevleri devleti temsilen belediye başkanı yerine getirir (Ulusoy ve Akdemir, 2013, s.154).

\section{Belediye (Comuni) Yönetimlerinin Organları}

Belediyelerin üç tane organı vardır: Belediye meclisi, Belediye encümeni ve Belediye başkanıdır.

\section{Belediye Meclisi (Consiglio Comunale)}

Belediye meclisi halk tarafından dört yıllık süre için seçilmektedir. Belediye meclisi, belediyenin karar organıdır. Meclis üyelerinin sayısı, belediyelerin büyüklüklerine göre değişiklik göstermektedir. En alt ve en üst sınır şu şekilde belirlenmiştir: Nüfusu üç binden az olan belediyelerde 12 kişi, nüfusu beş binden çok olan belediyelerde 60 kişidir.

Meclis seçimleri iki şekilde yapılmaktadır: Nüfusu beş binin üzerindeki belediyelerde nisbi temsil sistemi uygulanırken, nüfusu beş binin altındaki belediyelerde meclis üye sayısının 4/5'i için çoğunluk sistemi uygulanmaktadır (http://www.comunedisoglianocavour.gov.it).

\section{Belediye Encümeni (Giunta Cominale)}

Belediye encümeni, belediyenin yürütme organı olarak görev yapar. Belediye encümenine "Belediye giunta"sı da denir. Belediye encümeni, belediye başkanı ve çift sayıda belirlenmiş üyelerden oluşur. Belediye encümeni üye sayısı da belediyenin nüfusuna göre değişmektedir: Nüfusu üç binden az olan belediyelerde 2, nüfusu beş bin ve daha fazla olan belediyelerde 8 üye görev yapmaktadır. Belediye encümeninin görev süresi 4 yıldır (Tortop, 1996, s.67).

Encümen, belediye meclisinin kararlarını uygulamaya koyar, belediye meclisine belediye işleriyle ilgili öneriler sunar ve belediyenin günlük işlerini yürütür. Meclis toplantıda olmadığı zamanlarda belediye meclisini temsil eder ve bunun da ötesinde, belediye meclisi adına bir takım kararlar alabilir. Ancak böyle kararlar, ilk meclis toplantısında onaylanmak üzere meclise sunulur (Karabaş, 1991, s.56).

\section{Belediye Başkanı (Sindaco)}

Belediye başkanı, belediye meclisi üyelerinin seçim esaslarına göre seçilir. Belediye başkanı, belediye meclisinin ve idaresinin başıdır ve belediyeyi dışa karşı temsil etmektedir. Belediye meclisi ve yönetim kurulu kararlarının, imzalanan sözleşmelerin ve diğer belediye işlerinin uygulanması ve denetlenmesi için belediye başkanı tarafından gündem oluşturulur (Tortop, 1996, s.67). 
Başkan belediye meclisini ve encümenini toplantıya çağırarak, belediye teşkilatının çalışmasını düzenlemekle görevlidir. Belediye başkanının iki rolü vardır. Başkan hem belediyede çalışan koalisyonun başı hem de hükümetin idari temsilcisi olarak yasal görevleri yerine getirmektedir (Hine, 1993, s.276).

Başkan, belediye meclisi toplantılarında başkanlık yapar. Aynı zamanda belediyeyi mahkemede temsil eder. Merkezi yönetimin görevlisi olarak da devletin yasalarını, yönetmeliklerini ve bildirilerini yayınlamak zorundadır. Belediye başkanı, belediye encümeni üyelerini de atar. Belediye başkanı, Milano ve Roma gibi büyük şehirlerde ulusal seviyede önemli bir figürdür (Loughlin, 2001, s.217).

Belediye başkanı, kamu düzeni ve esenliğini sağlamak, toplum sağlığı ve bayındırlık işlerinde kimi işlevleri yerine getirmekten sorumludur. Belediye başkanının devlet temsilcisi olarak da bazı görevleri ve sorumlulukları vardır. Bunlar:

- Kamu düzeni, esenlik, güvenlik ve sağlıkla ilgili olarak kendisine yasayla verilen görevleri yerine getirir;

- Doğum, ölüm, evlenme gibi nüfus hareketlerinin kayıt altına alınmasını yapar, seçimle, askerlikle ve istatistik derlemeyle ilgili yasalarla belediyeye verilen işleri yürütür;

- Kamu güvenliği ve polisle ilgili yasalar tarafından kendisine verilmiş görevleri yerine getirir;

- Güvenlik ve kamu düzeniyle ilgili her türlü işleri gözetim ve denetim altında tutar ve valiye yaptığı işlerle ilgili bilgi sunar (Geray, 1997, s.57).

Belediye başkanı halkın güvenliği ve esenliği için gerektiğinde olağanüstü önlemler alabilir. $\mathrm{Bu}$ tür durumlarda silahlı güçlerinden destek sağlaması için validen talepte bulunabilir.

\section{Türkiye'de Belediye Yönetimi}

Türkiye’de, yerel nitelikteki birçok hizmetin görülmesini sağlayan ve demokratik hayatın gelişmesinde önemli rolü olan yerel yönetimler, il özel idareleri, belediyeler ve köylerdir. Bunların yanında, yerel yönetimlere benzeyen, fakat tüzel kişiliği olmayan "mahalle muhtarlıkları" vardır. Köyleri ayrı tutarsak bugünkü yerel yönetimlerin temelleri Tanzimat’tan sonra atılmıştır. Bu nedenle de il özel idareleri ve belediyeler Batılı ülkeler örnek alınarak kurulmuştur. Köyler ise, eski bir geleneğin devamıdır (Gözübüyük, 1971, s.121). Çalışmada Türkiye’deki yerel yönetim birimleri içerisinden belediyeler ele alınacağı için belediyelerin yapısı ve organları ile ilgili bilgi verilecektir.

\section{Belediye Yönetiminin Görevleri}

1982 Anayasası̉nın 127. maddesinde belirtilen yerel yönetim birimlerinden biri de belediyelerdir. Komün idarelerinin gerçek ve klasik örneğini teşkil eden belediyeler, beldenin ve belde sakinlerinin 
mahalli müşterek ihtiyaçlarını karşılamak üzere kurulan ve karar organı seçmenler tarafından seçilerek oluşturulan, idari ve mali özerkliğe sahip kamu tüzel kişileridir (5393 sayılı Belediye Kanunu, md.3). Belediyelerin tarihi Osmanlı Devleti’ne kadar gitmektedir. Gelişmiş batı ülkelerinde oldukça köklü bir geçmişe sahip olan bu birimler, bizde Tanzimat sonrasında ortaya çıkmıştır.

5393 sayılı Belediye Kanunu, kamu yönetiminin yeniden yapılandırılması çerçevesinde, belediye yönetiminde önemli yenilikler getirmiştir. Bu Kanunun, büyük ölçüde, Avrupa Yerel Yönetimler Özerklik Şartı, yeni kamu yönetimi anlayışı, gelişmiş ülke deneyimleri uygulamada ortaya çıkan sorunlar, ülkemizin reel gerçekleri ve 150 yıllık belediyecilik deneyiminin etkisi altında hazırlandığ 1 belirtilmektedir (Eryılmaz, 2010, s.151).

5393 sayılı Kanun'un 14. maddesinin 1. Fıkrasında, belediye görevleri iki bent halinde sayılmıştır. Bu görevlerin belediye tarafından yürütülmesinin temel şartı, hizmetin mahalli müşterek nitelikte olması olarak belirlenmiştir. İlk bentte yer alan görevlerin asli, ikinci bentte yer alan görevlerin ise diğer kurumların temel görevi olmakla birlikte isterse belediyelerin de yapabileceği nitelikte olduğu görülmektedir. İlk bentte yer alan hususlar belediye görevleri, ikinci bentte sayılan hususlar ise belediyelerin isterse yapabilecekleri hizmetleri ortaya koymaktadır.

Belediyeler için başka kanunlarda da özel olarak düzenlenmiş görevler verilmiştir. 5216 sayılı Büyükşehir Belediye Kanunu’nda da büyükşehir belediyesine verilen görevler 7. Maddede düzenlenmiştir.

Belediye hizmetlerinin yerine getirilmesinde öncelik sırası, belediyenin mali durumu ve hizmetin ivediliği dikkate alınarak belirlenmektedir. Ancak mali kaynakların planlaması açısından önemli olan bu düzenlemenin, öncelik sırasına ilişkin belirlediği kriterlerin neyi ifade ettiği açık değildir (Can, 2013, s.178).

Belediye hizmetleri, vatandaşlara en yakın yerlerde ve en uygun yöntemlerle sunulur. Hizmet sunumunda özürlü, yaşli, düşkün ve dar gelirlilerin durumuna uygun yöntemler uygulanır. Bunun yanında dezavantajlı toplumsal kesimlerin sorunlarının çözümünde de belediyeye görev vermekle sosyal belediyecilik olarak tanımlanan yaklaşıma yasa içinde yer vermiştir (Çukurçayır, 2013, s.184).

\section{Belediye Yönetiminin Organları}

5393 sayılı kanuna göre belediyelerin üç organı vardır. Bunlar; Belediye meclisi, Belediye encümeni ve Belediye başkanıdır. Bunlardan Belediye meclisi ve Belediye encümeni karar organı; Belediye başkanı ise yürütme organıdır.

\section{Belediye Meclisi}

Belediye meclisi, belediyenin en büyük karar organıdır. Üyeleri beş yılda bir nispi temsil yöntemiyle doğrudan doğruya halk tarafından seçilir. Belediye meclisi üye sayısı kentin büyüklüğüne, yani 
nüfusa göre değişir. Nüfusu 10.000 'den az olan belediyelerde, üye sayıs1 9'dur. Nüfusu 10.000'i geçen belediyelerde, üye sayısı da nüfusla birlikte artmaktadır (Keleş, 2012, s.270).

Belediye meclisine, belediye başkanı başkanlık eder. Belediye başkanının katılmaması durumunda birinci başkan vekili, meclise başkanlık eder. Ancak yıllık faaliyet raporunun görüldüğü meclis toplantısına belediye başkanı başkanlık yapamaz bu nedenle toplantı başkan vekilinin başkanlığında yapılmaktadır.

Belediye yürütme organı olan belediye başkanının belediye karar organı olan belediye meclisine başkanlık ederek belediye meclisinin işlerine müdahale etmesi uygun değildir (Dursun, 2007, s.383). Belediye meclisinin seçilmiş bir başkana sahip olması meclis başkanının prestijini yükseltecek ve törensel görevlerinin önemini büyütecektir.

Meclis toplantılarıyla ilgili yapılan düzenleme (İçişleri Bakanlığına yapılacak toplantı ile ilgili bilgi verme, toplantı gündeminden mülki amirin haberdar olması gibi uygulamaların kaldırılması) ile birlikte idari vesayet kaldırılmıştır. Bu durum yerel yönetimlerin özerkliği açısından olumlu bir gelişmedir. Belediye meclisinin her toplantısını, yerini, gündemini adım adım merkezi otoritenin ve mülki amirlerin takip etmesi, özerkliği zedelemekteydi ve yapılan düzenlemeyle bu durum değiştirildi.

Belediye Meclisinin görev ve yetkileri kanunun 18. maddesinde belirtilmektedir. 5393 sayılı kanun, merkezi idareye belediye meclisi kararları üzerinde vesayet yetkisi neredeyse tanımamıştır. Sadece kanunun 81. maddesinde; cadde, sokak, meydan, park, tesis ve benzerlerine ad verilmesi ve beldeyi tanıtıcı amblem, flama ve benzerlerinin tespitine ilişkin kararlarda belediye meclisinin karar yeter sayısı ağırlaştırılmış ve bu kararların mülki amirin onayı ile yürürlüğe gireceği belirtilmiştir. Belediye meclisinin söz konusu kararları dışında başkaca bir vesayet yolu öngörülmemiştir.

Meclis kararlarının kesinleşmesi ile ilgili yapılan düzenlemede; meclis tarafından onaylanan kararlar kesinleştiği tarihten itibaren en geç yedi gün içinde mahallin en büyük mülkü amirine gönderilmekte ve mülki idare amirine gönderilmeyen kararlar yürürlüğe girmemektedir. Kesinleşen meclis kararları çeşitli araçlarla halka duyurulmaktadır. Buradaki düzenlemenin bir denetim değil, bilgilendirme ve aleniyet olduğu görülmektedir.

5393 sayılı kanunla merkezi idarenin belediyeler üzerindeki vesayet yetkisinin neredeyse kaldırılması, Avrupa Yerel Yönetimler Özerklik Şartına uygun bulunmaktadır (Dursun, 2007, s.389-390).

\section{Belediye Encümeni}

5393 sayılı Belediye Kanunu'nun 33. Maddesine göre bir idari ve uzmanlık organı olarak düşünülen belediye encümeni, belediye başkanının başkanlığında toplanarak Belediye Kanunu'nun 34 . maddesinde belirtilen görev ve yetkileri yerine getirmektedir. 
Belediye encümeninin oluşum tarzı; atanmışlar ve seçilmişler olmak üzere iki türlü olarak düzenlenmiştir. İl belediyelerinde ve nüfusu 100.000 'in üzerindeki belediyelerde, belediye meclisinin her yıl kendi üyeleri arasından bir yıl için gizli oyla seçeceği üç üye, mali hizmetler birim amiri ve belediye başkanının birim amirleri arasından bir yıl için seçeceği iki üye olmak üzere yedi kişiden, diğer belediyelerde ise belediye meclisinin her yıl kendi üyeleri arasından bir yıl için gizli oyla seçeceği iki üye ile mali hizmetler birim amiri ve belediye başkanının birim amirleri arasından bir yıl için seçeceği bir üye olmak üzere beş kişiden oluşmaktadır.

5393 sayılı Kanun'un 35.maddesine göre, belediye encümeninin gündemi belediye başkanı tarafından hazırlanacağı, encümen üyelerinin belediye başkanının uygun görüşü ile gündem maddesi teklif etmesinin olanaklı olduğu, encümene havale edilen konuların bir hafta içerisinde görüşülerek karara bağlanacağı ifade edilmiştir. Bu düzenlemeler, encümende belediye başkanının ağırlıkta olduğu bir yapıyı getirmektedir.

5393 sayılı kanunun 34. maddesinde belediye encümeninin görevleri liste hâlinde tek tek sayılmış, liste dışındaki konularda ise belediye encümeninin aktarılmış bir yetkiye sahip olduğunu belirten bir hükme yer verilmemiştir. 5393 sayılı kanunun 34. maddesinin incelenmesi sonucu; belediye encümeninin danışma görevlerinin yanı sıra hatta ondan daha ağırlıklı olmak üzere icrai karar alma görev ve yetkileriyle donatıldığı gözlenmektedir.

\section{Belediye Başkanı}

Tek seçim çevreli dar bölge sistemine göre çoğunlukla seçilen belediye başkanı, belediye idaresinin başı ve belediye tüzel kişiliğinin temsilcidir. Belediye başkanının görevleri 5393 sayılı Belediye Kanunu’nun 38.maddesinde belirtilmiştir. Belediye başkanı, meclise ve encümene başkanlık yapar. Belediye meclisinin ve encümenin kararlarını uygular (5393 sayılı Belediye Kanunu, md.38).

Belediye başkanı, görev süresi boyunca siyasi partilerin görev ve denetim organlarında görev alamamakta, profesyonel spor kulüplerinin başkanlığını yapamamakta ve yönetiminde bulunamamaktadır. Belediye başkanı izin, hastalık veya başka bir sebeple görev başında bulunmadı̆̆ı durumlarda, bu süre içinde kendisine vekâlet etmek üzere, belediye meclisi üyelerinden birini başkan vekili olarak görevlendirmektedir (5393 sayılı Belediye Kanunu, md.37). Belediye başkanının görev ve yetkileri kanunun 38. maddesinde sıralanmıştır.

Belediye başkanını görevleri şu şekildedir (5393 sayılı Belediye Kanunu, md.38):

- Belediye teşkilâtının en üst amiri olarak belediye teşkilâtını sevk ve idare etmek, belediyenin hak ve menfaatlerini korumak.

- Belediyeyi stratejik plâna uygun olarak yönetmek, belediye idaresinin kurumsal stratejilerini oluşturmak, bu stratejilere uygun olarak bütçeyi, belediye faaliyetlerinin ve 
personelinin performans ölçütlerini hazırlamak ve uygulamak, izlemek ve değerlendirmek, bunlarla ilgili raporları meclise sunmak.

- Belediyeyi Devlet dairelerinde ve törenlerde, davacı veya davalı olarak da yargı yerlerinde temsil etmek veya vekil tayin etmek.

- Meclise ve encümene başkanlık etmek.

- Belediyenin taşınır ve taşınmaz mallarını idare etmek.

- Belediyenin gelir ve alacaklarını takip ve tahsil etmek.

- Yetkili organların kararını almak şartıyla sözleşme yapmak.

- Meclis ve encümen kararlarını uygulamak.

- Bütçeyi uygulamak, bütçede meclis ve encümenin yetkisi dışındaki aktarmalara onay vermek.

- Belediye personelini atamak.

- Belediye ve bağlı kuruluşları ile işletmelerini denetlemek.

- Şartsız bağışları kabul etmek.

- Belde halkının huzur, esenlik, sağlık ve mutluluğu için gereken önlemleri almak.

- Bütçede yoksul ve muhtaçlar için ayrılan ödeneği kullanmak, engellilere yönelik hizmetleri yürütmek ve engelliler merkezini oluşturmak

- Temsil ve ağırlama giderleri için ayrılan ödeneği kullanmak.

- Kanunlarla belediyeye verilen ve belediye meclisi veya belediye encümeni kararını gerektirmeyen görevleri yapmak ve yetkileri kullanmak

Belediye başkanının görevleri arasında stratejik plan ve performans programı hazırlanması da bulunmaktadır. Belediye Kanunu'nun 41. maddesinde, belediye başkanı, yerel yönetimler genel seçimlerinden itibaren altı ay içinde; kalkınma planı ve programı ile varsa bölge planına uygun olarak stratejik plan ile ilgili olduğu yılbaşından önce de yıllık performans programı hazırlayıp belediye meclisine sunmaktadır (5393 sayılı Belediye Kanunu, md. 41). Belediyelerin stratejik plan ve bu plan doğrultusunda, yıllık çalışma programlarını, bütçelerini ve performans ölçütlerini oluşturmaları gelecek yönelimli, sonuç odaklı ve etkin ve verimli bir yönetim anlayışı ve yapısının tesisi açısından önemlidir (Ökmen ve Parlak, 2013, s.262).

\section{Yerel Özerklik, Mali Özerklik ve İdari Vesayet Kavramları}

"Yerel yönetimler, devlet tüzel kişiliği dışında ayrı tüzel kişiliğe ve özerkliğe sahip bulunan yerinden yönetim kuruluşlarıdır. Yerel yönetimler, yerel özerkliğe sahip olmakla birlikte, kullandıkları yetkiler kendilerine merkezi yönetim tarafından verilmektedir” (Ünal, 2013, s.57).

Özerklik kavramı, kurumların kendi öz sorumlulukları altında kendi hizmetlerini düzenleme hakkıdır şeklinde tanımlanmaktadır. Merkezden yönetimin sakıncalarını gidermek ve azaltmak 
için düşünülen yerel özerklik; yerel yönetimlerin kendilerine tahsis edilmiş hizmetleri, ülke yararları doğrultusunda sunmaları sürecindeki davranış özgürlügünün derecesi ile ilgilidir (Tortop, 1996a, s.12). Yoksa merkezi yönetimle hiçbir hukuki, teknik vs. ilişkisi olmayan, merkezi yönetimden tamamıyla kopuk bir yerel yönetim anlayışı yerel özerklik kavramının hedefi değildir (Çelebi, 2003, s.53).

Yerel özerklik (Local Autonomy) ise, yerel yönetimlerin kamu hizmetlerini daha iyi yerine getirebilmesi, bu hizmetleri yerine getirirken merkezi yönetimin ya da onların ajanlarının bir müdahalesi olmadan karar alabilmesi, böylece yerel toplulukların yerel nitelikteki işleri kendi sorumlulukları altında özgürce verebilmeleri, katılımcı demokrasiyi hayata geçirmesi ve daha da güçlendirmesi anlamına gelmektedir (Çelik vd, 2008, s.95). Bu nedenle yerel yönetimlerin özerk bir kuruluş niteliği kazanabilmesi için, öncelikle seçimle iş başına gelen karar organlarının olması ve bu karar organlarıyla dışarıdan hiçbir baskı ve karışma olmadan kendi işlerini yapabilmeleri gerekmektedir (Keleş, 2012, s.52).

Avrupa Yerel Yönetimler Özerklik Şartı’nda özerk yerel yönetim kavramı şu şekilde yapılmıştır: "yerel makamların, kanunlarla belirlenen sınırlar çerçevesinde, kamu işlerinin önemli bir bölümünü kendi sorumlulukları altında ve yerel nüfusun çıkarları doğrultusunda düzenleme ve yönetme hakkı ve imkânı anlamını taşır” (Keleş, 2012, s.56).

Avrupa Yerel Yönetimler Özerklik Şartı’nda ifade edildiği gibi özerklikle amaçlanan, merkezi yönetimin ve bürokratik çalışmaların sakıncalarını gidermektir. Yetkilerin tek elde toplanması, kararların merkezden alınması yürütmeyi geciktirmekte hizmetlerde bir yavaşlama meydana gelmektedir (Tortop, 1991, s.3). Bu sistemi daha verimli, hızlı ve demokratik bir yapı haline getirebilmek için yerel yönetimlerin özerk olması önem teşkil etmektedir. Yerel özerkliğin sağlanmasıyla birlikte merkezi yönetimin yoğun vesayeti de sınırlandırılmış olacaktır. Böylece yerel yönetimlerde görevlerini yerine getirirken merkezin yoğun vesayetinden kurtulmuş olacak ve yerel yönetimler kanunlar çerçevesinde karar verme serbestisine sahip olabilecektir.

Yerel özerkliğin tam anlamılla var olabilmesi yerel yönetimlerin mali özerkliğe sahip olması da oldukça önemlidir. Mali özerklik, yerel yönetimlerin merkezi yönetime muhtaç olmadan, kendilerine verilen görev ve sorumluluklarını yerine getirebilecek kadar serbestçe harcayabilecekleri yeterli gelir kaynaklarına sahip olması şeklinde tanımlanabilir. Kendilerine verilen görevleri yerine getirebilmeleri bağlamında yerel yönetimlerin görevleri ile orantılı gelire sahip olmaları mali özerklik için önemlidir. Bu nedenle yerel yönetimlerin gerçek anlamda var olabilmesi için idari özerkliğin yanında mali açıdan da özerk olması gerekir. Yani yerel yönetimlerin yasal düzenlemelerle merkezi yönetimden aldıkları payların dışında gelir kaynaklarına sahip olmaları ve kendi organlarının kararlarına dayanarak harcama yapabilmelidirler (Egeli ve Diril, 2012, s.27).

Yerel yönetimlerde etkinlik, sosyal adalet ve tarafsızlık bu idarelerin görevlerini yerine getirebilecek düzeyde gelire sahip olmalarıyla sağlanabilir (Yüksel, 2005, s.283). Bir diğer tanıma göre mali özerklik, kurumların çeşitli yollardan gelir oluşturmaları, gelirlerini ve varlıklarını kendi amaçlarına uygun bir biçimde kullanabilmeleri ve esnek bir bütçe sistemine sahip olmalarıdır 
(Egeli ve Diril, 2012, s.27). Bu yerel yönetimlerin yeterli mali kaynağa sahip olabilmeleri için, her şeyden önce merkezi yönetimle yerel yönetimler arasında iyi bir gelir bölüşümü yapılması gerekmektedir. Merkezi yönetimle, yerel yönetimler arasında gelir bölüşümü sistemi, yerel yönetimlerin mali özerkliğinin temelini oluşturmaktadır (Açıkgöz, 2007, s.19).

Mali özerkliğin koşullarını dört başlık altında toplayabiliriz.

- Mali kaynakların çoğunluğunun öz gelirlerden oluşması,

- Öz gelirlerin oranlarını belirleyebilme,

- Merkezi yönetim yardımlarının şartsız verilmesi,

- Gelirlerin serbestçe harcanabilmesidir.

Mali özerkliğin özelliklerine değinmek gerekirse (Egeli ve Diril, 2012, s.27-28):

- Mali özerklik, öncelikle gelir ve harcama boyutlarıyla birlikte ele alınmalıdır. Yönetim gelirleri harcamalara göre belirlemelidir. Harcamaların belirlenmesinde örneğin; halka açık hizmetlerin ücretlendirilmesi gibi ağırlıklı olarak hizmetlerden yararlananlar tarafından finansmanın sağlandığı harcama kaynak ilişkisi sağlanmalıdır.

- Mali özerkliği değerlendirmede kuvvetli bir merkezi gözlem ve değerlendirme yeteneği olmalıdir.

- Yerel yönetimlere belirli ölçülerde vergilendirme yetkisi tanınmalıdır.

- Merkezi yönetim, koyduğu mali özerklik kurallarını koruyabilmelidir.

- Mali özerklik kapsamında oluşturulan sistem basit ve anlaşılır olmalıdır.

- Yönetimler arası vergilendirme yetkisinin devri mali özerkliğin amacına uygun olmalıdır.

Bu özellikler mali özerklikle istenilen amaca ulaşılıp ulaşılmadığını tespit etmekte önem teşkil etmektedir. Yerel yönetimlerin etkin, tarafsız, yerinde ve hızlı hizmet verebilmesi için idari özerkliğin yanında mali özerkliğin de var olması gerekir.

Özerklik ve denetim kavramları birbirleriyle ilişkili kavramlardır. Yerel yönetimlerin merkezi yönetim tarafından kanunların öngördüğü sınırlar içinde denetlenmesine, idari vesayet denetimi denilmektedir. Yerel yönetimler açısından idari denetim, idari kurum, vasıta ve usullerle yapılan ve yerel yönetimlerin işlemleri, eylemleri, organları ve personeli üzerinde cereyan eden bir denetim şeklidir. İdari vesayet, değişik şekillerde isimlendirilmiştir. "İdari vesayet", "idari vesayet denetimi“ ve "idari vesayet yetkisi" olarak da isimlendirildiği görülmektedir.

"İdari vesayet; merkezin ademi merkeziyet idarelerinin icrai kararlarm ve idari fill ve hareketlerini murakebe etmek ve bu kararları bozabilmek salahiyetidir" (Onar, 1960, s.622).

Yerel yönetimlerin yönetsel denetiminde aşırıya kaçılması, yoğun bir denetim uygulanması, bu kuruluşların özerkliğini zedeleyebileceği gibi denetimden beklenen yaraların elde edilmesine de engel olabilir. Bu nedenle yerel yönetimlerin idari vesayet denetimi, bu kuruluşların özerkliğine 
zarar vermeyecek ölçüde, gelişmelerini teşvik edici, faaliyetlerinde yol gösterici olarak gerçekleştirilmesi gerekmektedir (Ünal, 2013, s.44).

"Katı bir merkezi yönetimin sakıncaların ortadan kaldırmak ve yönetimde verimlilik ve etkinliği en iyi bir şekilde gerçekleştirebilmek ve devletin yüklendiği çeşitli ekonomik ve toplumsal görevlerin yerine getirilmesini kolaylaştırmak amacıyla, yerel yönetim birimlerine, kendi organları eliyle bağımsız olarak aldıkları kararları uygulama hakkı ve kamu hizmeti yapan kuruluşlara da yasalarla hukuki kişiliği (tüzel kişilik) kazandırılarak yine çalışma alanlarında bağımsız bir şekilde kendi organları eliyle uygulama olanağı tanımıştır. Ancak kamu düzeni ve kamu yararı bakımından merkezi yönetim, belirli konularda yerel yönetim veya kamu hizmeti yönetim tüzel kişisini çeşitli şekillerde denetleme yetkisini saklı tutmuştur. Bu denetim ilişkisi idari vesayeti oluşturmuştur" (Çoşkun, 1996, s.36).

Yerinden yönetim, yerel nitelikteki yönetsel yetki ve görevlerin yerel yönetim birimlerine merkezi yönetim tarafından devredilmesini sağlayan bir yöntem olup bununla birlikte yerel yönetimlerin işlem ve eylemleri devlet tarafından denetlenmektedir ve yerel yönetimler kanunlara uygun olarak hareket etme sorumluluğuna sahiptir (Aktalay, 2010, s.120).

Ancak merkeziyetçi yapıya sahip devletlerde, yerel yönetimlerin özerkliği merkezi yönetimden tamamen bağımsız olarak faaliyet yürütmek anlamında karşılık bulmamaktadır. Hiçbir toplumda merkezi yönetim ile yerel yönetimleri birbirinden tamamen bağımsız olarak düşünmek mümkün olmadığından yerel hizmetlerin yürütülmesi, merkezi yönetim ile yerel yönetimlerin ayrılığını değil yetki ve görevlerin iş bölümü içinde paylaşılması sonucu tamamlayıcıllğı ifade eder (Ekici ve Toker, 2005, s.6).

Merkezi yönetim, yerel yönetimlere verdiği yetkilerin hukuk kurallarına, devletin genel menfaatlerine, birlik ve bütünlügüne aykırı şekilde kullanılmasını önlemek ve devlet hizmetlerinde ahengi sağlamak için, yerel yönetimleri denetim ve gözetim altında tutmaktadır (Ünal, 2013, s.57).

İdari vesayet denetiminin yetkisi yasayla belirlenmektedir. Bununla birlikte genelge, sirküler, sorulan sorulara görüş bildirme ve merkezi yönetimin önerilerde bulunması gibi yasayla doğmayan düzenlemeler de yapılabilmektedir (Türkyılmaz, 2014, s.18). Bunun sonucu olarak yerel yönetimler, merkezi yönetimin çeşitli birimleri tarafından denetlenmektedir. "İdari vesayet yüksek yargı organlarının vermiş olduğu çeşitli kararlarda uygulama açısından tanımlanmış ve sınırları çizilmiştir. Bu bağlamda, Danıştay’ın vermiş olduğu bir kararda idari vesayet "kamu düzenini ve idarede bütünlüğü sağlamak için, kamu yararı amacıyla, yerinden yönetim idarelerinin işlemlerini denetleme yetkisi” olarak tanımlanmıştır” (Şensoy, 2010, s.112).

İdari vesayet denetimi, kanuna dayanmak ve onunla sınırlı olmak üzere, kanunla yetkili kılınmış yönetsel organ, makam veya kişi tarafından, esas itibariyle devletin genel menfaatlerini, devletin birlik ve bütünlügünü, kamu hizmetlerinin ahengini sağlamak ve korumak, aynı zamanda halkı 
yerel yönetimlerin keyfi eylem ve işlemlerden korumak amacıyla, yerel yönetimlerin eylem ve işlemleri, organları ve personeli üzerinde uygulanmaktadır.

İdari vesayet ve yerel özerklik arasında ters orantılı bir ilişki vardır. İdari vesayet denetimi arttıkça özerklik alanı daralır; denetim azaldıkça özerkliğin alanı genişler. Bu nedenle yerel yönetimler üzerindeki denetimin sınırları oldukça önemlidir. Yerel yönetimlerin özerkliğini zedelememek için denetimin sınırı ve kapsamı iyi belirlenmeli ve uygulanmalıdır (Keleş, 1997, s.10).

Avrupa Konseyi tarafından hazırlanan Avrupa Yerel Yönetimler Özerklik Şartı da özerk yerel yönetimlerin nasıl olması gerektiğine açıklık getirerek hukuki denetimin öneminden bahsetmiş ve denetimin sınırının iyi bir şekilde belirlenmesi gerektiğini ifade etmiştir. Bir sonraki bölümde AYYÖŞ bağlamında İtalya ve Türkiyedeki belediye yönetimlerinin idari vesayet yönünden karşılaştırılması yapılacaktır.

\section{Avrupa Yerel Yönetimler Özerklik Şartı Bağlamında: İtalya ve Türkiye'deki Yerel Yönetimler Üzerinde İdari Vesayet Denetimi}

Klasik temsili demokrasinin, yönetim ve denetim anlayışına hızlı cevap vermede yetersiz kalması, halkın yönetime daha aktif katılmak istemesi, yerel yönetimlerin güçlendirilmesi ve yerel yönetimler üzerindeki merkezi denetimin en aza indirilmesi konularındaki isteklerin artması, bu taleplerin uluslararası platformlarda, belgelerde ve anayasalarda daha açı bir şekilde yer almasına neden olmuştur. Yerel, bölgesel ve ulusal düzeyde yaşanan sorunların en iyi çözüm yolunun yerelde aranması yerel ve bölgesel yönetimlerin öneminin ön plana çıkmasına ve görev alanlarının artmasına neden olmuştur (Ekici ve Toker, 2005, s.5). Bunun yanında Avrupảnın bütünleşme süreci de, yerel yönetimlerin ön plana çıkmasında önemli bir etki yaratmıştır. 1970'li yıllardan itibaren yerel ve bölgesel politikaların canlandırılmaya çalışılması, yapısal fonların oluşturulması, yerel yönetimlerin ön plana çıkma sürecini hızlandırmıştır (Arıkan, 2004, s.46). Yerel yönetimlerin üstlendikleri görevler, bugün eskiye oranla önemli bir artış göstermiştir. Ancak bu değişim ülkelerin tarihsel süreç içinde sahip oldukları merkeziyetçi, adem-i merkeziyetçi eğilimler ve benimsedikleri farklı yönetim sistemleri nedeniyle, yerel yönetimlerin üstlendikleri görevlerin kapsamı da ülkeden ülkeye farklılık göstermektedir.

Ülkeden ülkeye değişiklik gösteren yönetim sistemleri, yerel yönetimlerin özerklik dereceleri, yerel demokrasinin gelişmesi ve daha demokratik yönetim anlayışının varlığı açısından büyük önem taşımaktadır. Yerel demokrasinin önemi Avrupa Konseyi üye ülkeleri tarafından kabul edilmiş ve bunun üzerine Konsey, yerel yönetimlerin haklarını ve yetkilerini garanti altına almak için yerel yönetimlerin özerkliği üzerine çalışmalar yapmaya başlamıştır. Konsey tarafından hazırlanan ve 1 Eylül 1988 tarihinde yürürlüğe giren Avrupa Yerel Yönetimler Özerklik Şartı, Avrupa Birliğỉnin yerel yönetim politikasının da temelini oluşturmaktadır. Avrupa Yerel Yönetimler Özerklik Şartı’nda yerel yönetimlerin tanımı, görev ve yetkileri, yerel yönetimlerin sınırlarının değiştirilmesi, mali kaynaklar, birlik kurabilme ve yerel yönetimlerin hukuki açıdan nasıl korunacağı gibi önemli noktalar maddeler halinde düzenlenmiştir (Mengi, 2007, s.107). 
Şart'ın amac1, yerel yönetimlerin mali ve idari özerkliğini sağlayacak ilkelerin üye ülkeler tarafından benimsenmesini ve hayata geçirilmesini sağlamaktır. Uluslararası antlaşma niteliğinde olan ve metinde yer alan maddeler ilke düzeyinde ifadelerdir. Şart özerk yerel yönetimleri şu şekilde tanımlamaktadır:

“Özerk yerel yönetim kavramı yerel makamların, kanunlarla belirlenen sinırlar çerçevesinde, kamu işlerinin önemli bir bölümünü kendi sorumlulukları altında ve yerel nüfusun çıkarları doğrultusunda düzenleme ve yönetme hakkı ve imkânı anlamını taşır“.

AYYÖŞ’ü imzalayan ülkelerin, kendi iç hukuklarında bu ilkelere uygun düzenlemeleri yapmaları beklenmektedir. Bunun yanında Şart'ın mümkün olduğunca çok ülke tarafından imzalanması amacıyla, ülkelere bazı maddeleri seçmeleri, bazılarına ise çekince koymaları imkânı tanınmıştır. Birlik ülkelerinin her biri yerel yönetimlerle ilgili temel yasalara sahiptir ve bunları tek bir çerçeve yasa, bir tür ülkeye özgü yerel özerklik şartı çatısı altında toplamak eğilimindedirler (Arıkan, 2004, s.46). AYYÖŞ Avrupa Konseyi üyesi olan 47 ülke içinden 44 ülke tarafından imzalanmış ve yürürlüğe konulmuştur. Kendi iç hukuklarına göre de düzenlemeler yapmışlardır. Bu ülkelerden İtalya ve Türkiye'yi karşılaştırdığımızda bize yönetim sistemlerinin farklılıklarının yerel yönetimlerin özerkliği ve görevlerinin kapsamı üzerindeki etkisi açısından önemli bir örnek oluşturmaktadır.

İtalya Cumhuriyeti kurulduğu günden itibaren yoğun merkeziyetçi bir eğilim göstermiştir. Ancak 1970’li yıllarda bu merkeziyetçi eğilimden vazgeçerek İtalyan Anayasası'nın 5. Maddesinde "Cumhuriyet birdir, bölünemez, yerel özerklikleri tanır ve destekler" Anayasa’nın 114. maddesinde ise, İtalya bölgelere, illere ve komünlere ayrılmış yerel ve bölgesel yönetimlerin varllğ 1 anayasal güvence altına alarak korumuştur.

İtalya'da ülkenin yönetim sistemi açısından genel olarak hükümetler ve kamuoyunda bütünleşme yanlısı bir görünüm çizilmekle birlikle; yerel yönetimlere verilen yetkiler incelendiğinde tam tersi bir görünümle karşılaşılmakta bu da İtalyan paradoksu olarak adlandırılmaktadır (Arıkan, 2004, 42). Bütünleşme yanlısı görünüme karşın, İtalya bugün demokratik bir cumhuriyet olarak beşözel statülü ve geniş yetkilere sahip olan özerk bölge ve on beş daha az yetkili normal statülü bölgeye sahiptir. Bunların dışında, belediyeler (komünler), iller ve metropol şehirlerin ayrı düzenlemeleri bulunmaktadır. İtalya Cumhuriyeti, yerel yönetim birimlerini daha özerk hale getirebilmek için 1990 ’l yıllarda anayasada önemli reformlar yapmıştır. Anayasada metropol şehirler kurularak yetkilerin bu metropol şehirlerin yerel yönetimlerine bırakılması kararlaştırılmışsa da bu düzenleme tam olarak uygulamaya geçirilememiştir. Bugün halen bazı şehirler, metropol şehir kapsamında olmasına rağmen bunlara ilişkin yasal düzenlemelerin uygulanmadığı görülmektedir.

İtalya 11.05.1990 tarihinde Avrupa Yerel Yönetimler Özerklik Şartı’nı imzalamış ve Şart, aynı yıl 1 Eylül'de yürürlüğe girmiştir. İtalya Cumhuriyeti, AYYÖŞ’ü imzalayarak yerel yönetimleri daha özerk bir yapıya kavuşturmak için önemli bir adım atmıştır. Anayasası’nda yaptı̆̆ı reformlarla 
yerel yönetimlere verilen yetkilerin artırılması, yerel yönetimlerin üzerindeki denetimin azaltılması da yerel yönetimlerin özerkliği için önem arz etmektedir.

Türkiye Cumhuriyeti’nin tarihsel sürecine baktığımızda ise, merkeziyetçilik açısından İtalya’dan pek de farklı olmadığını söyleyebiliriz. Türkiye’de 1982 Anayasası’nın 3. maddesinde Türkiye Devleti, ülkesi ve milletiyle bölünemez bir bütündür" denilmektedir. Anayasada "demokrasi ilkesi“ ve "özerklik" terim olarak geçmemekle birlikte, yerel yönetimlerin kuruluş ve işleyiş biçimlerine ilişkin hükümler demokrasi ve özerklik ilkesi dikkate alınarak oluşturulmuştur (Uygun, 2015, s.8). 1982 Anayasası'nda yerel yönetim birimleri iller, belediyeler ve köyler olarak sayılmaktadır ve mahalli idarelerin kuruluş ve görevleri ile yetkileri, yerinden yönetim ilkesine uygun olarak kanunla düzenlenir denilmektedir (md.127).

Türkiyede İtalya gibi şartı imzalayan ve parlamentosunda onaylayan Konsey ülkelerinden biridir. Türkiye Avrupa Yerel Yönetimler Özerklik Şartı’nı 21.11.1988 tarihinde imzalamış, anlaşma 9.12.1992 tarihinde TBMM'de onaylanmış ve 1.4.1993 tarihinde yürürlüğe girmiştir.

Avrupa Yerel Yönetimler Özerklik Şartı, merkezi yönetimin yerel yönetimler üzerindeki yönetsel denetim ve gözetim (vesayet) yetkisinin, eylem ve işlemlerinin yalnızca hukuka uygunluk yönünden kullanılabileceğini öngörmekte, yerindelik denetimine izin vermemektedir. Şart ayrıca, bu yönetimler üzerindeki merkezi denetim ve gözetimin, bu denetim ve gözetimden beklenen yararlarla orantılı olmasını da şart koşmaktadır. Başka bir şekilde ifade etmek gerekirse; bu orant1lılık ilkesi, merkezi yönetimin, elindeki denetim ve gözetim yetkisini, yerel yönetimleri baskı altında tutmak gibi amaçlarla kullanamayacağı anlamına gelmektedir.

Türkiyede Şart’ta belirtildiği gibi, üniter devlet yapısı içinde idarenin bütünlügünü sağlamak amacıyla; yerel yönetim birimlerinin organları, kararları, eylem ve işlemleriyle ilgili merkezi yönetimin yapacağı denetim açısından, Anayasa hukuka uygunluk denetimini öngörmektedir.

Türkiye’nin Avrupa Yerel Yönetimler Özerklik Şartı’nı imzalamasıyla birlikte yerel yönetimlerin özerkliğini koruma altına almak için reformlar yapmış; 5393 sayılı Belediye Kanunu, 5216 sayılı Büyükşehir Belediye Kanunu ve 5302 sayılı İl Özel İdaresi Kanunu ile Şarta uygun birçok değişiklik yapılmıştır.

Türkiyede AYYÖŞ’te belirtilenenin aksine, Anayasa vesayet denetimini, yalnızca hukuka uygunluk ilkesiyle sınırlandırmamış, ona yerindelik unsuru da eklemiştir. Anayasada vesayetle ilgili belirtilen ilkelerden "toplum yararının korunması" ve "mahalli ihtiyaçların gereği gibi karşılanması" ilkeleri, hukuka uygunluk değil, yerindelik denetimini zorunlu kılmaktadır. Toplum yararına uygunluğun ölçüsünü, herkesçe kabul edilebilir objektif ölçüte bağlamak zordur. Anayasada yer alan "toplum yararının korunması" ve "mahalli ihtiyaçların gereği gibi karşılanması" ilkeleri herkesçe kabul edilebilir objektif ölçütler değildir. Bu maddelerde netlik olmamakla birlikte farklı siyasi kesimlerin bu durumu kendi lehlerine kullanabilmelerine olanak sağlamaktadır. Bu iki madde gibi objektifliğe ve hukuki bir ölçüte bağlanamayan denetim ilkeleri, keyfi tasarruflara neden olabilir. $\mathrm{Bu}$ nedenle idari vesayet denetiminin hukukilik ölçütüyle sınırlandırılması 
gerekir ki idari vesayet denetimi yapılırken yerel yönetimlerin özerkliği zedelemesin (Eryılmaz, 2015, s.224). Dolayısıyla Anayasada yeni düzenlemelere gidilmesi yerel yönetimlerin özerkliği açısından önem taşımaktadır. Bu şekilde belirsiz düzenlemeler keyfi müdahalelere kapı açmakta.

Avrupa Yerel Yönetimler Özerklik Şartı’nı kabul eden Türkiye, Şartı imzalayıp onaylamasına rağmen 10 paragrafına çekince koymuştur. İtalya ise AYYÖŞ’ün tüm maddelerini kabul etmiştir.

\begin{tabular}{|l|l|}
\hline İtalya ve Türkiye'nin Avrupa Yerel Yönetimler Özerklik Şartı'nda Çekince Koyduğu Maddeler: \\
\hline İTALYA & Çekince konulan madde yoktur. \\
\hline TÜRKIYE & Madde 4, Madde 6, Madde 7, Madde 8, Madde 9, Madde 10, Madde11 \\
\hline
\end{tabular}

Kaynak: (Sobac1, 2015, s.15).

İtalya'daki yerel ve bölgesel yönetimlerle Türkiye’deki yerel yönetimler karşılaştırıldığında kuruluş, yapılanma, görev kapsamı ve özerklik dereceleri arasında önemli farkların olduğu görülmektedir. İki ülke AYYÖŞ’e koyduğu çekinceler bağlamında incelendiğinde İtalya’nın Şartı tümüyle kabul ettiğini ve hiçbir maddesine çekince koymadığını, Türkiye'nin ise özellikle mali özerklikle ilgili maddelerine çekince koyduğunu görüyoruz. İtalya, yerel yönetimlerinin özerkliğini tam anlamıyla sağlayabilmek ve koruyabilmek için Şart'ın tüm maddelerini kabul etmiş, Türkiye ise merkeziyetçi yapısının zarar görmesinden çekindiği için bazı maddeleri kabul etme konusunda çekimser kalmıştır.

Şart’ın 8. Maddesi, yerel yönetimler üzerindeki idari denetimin (vesayetin) niteliği, kapsamı ve uygulanma yöntemi ile ilgilidir. Türkiye bu maddenin üçüncü paragrafına çekince koymuş ilk iki paragrafını ise kabul etmiştir. İlgili madde şu şekildedir:

1. Yerel yönetimlerin her türlü idari denetimi ancak kanunla veya anayasa ile belirlenmiş durumlarda ve yöntemlerle gerçekleştirilir.

2. Yerel yönetimlerin faaliyetlerinin idari denetimi normal olarak sadece kanunla ve anayasal ilkelerle uygunluk sağlamak amacıyla yapılacaktır. Bununla beraber, üst yönetimler yerel yönetimleri yetkili kıldıkları işlerin gereğine göre yapılıp yapılmadığını idari denetimine tabi tutabileceklerdir.

3. Yerel yönetimlerin idari denetimi, denetleyen makamın müdahalesinin korunması amaçlanan çıkarların önemiyle orantılı olarak sınırlandırılmasını sağlayacak biçimde yapılmalıdır (AYYÖŞ, md.8).

Özerklik şartı prensip olarak, idari vesayeti, hukuka uygunluk denetimiyle sınırlandırmıştır. Şart’a göre, sadece merkezi idare kuruluşlarına ait olup da, yerel yönetim birimlerine yaptırılan hizmetler açısından yerindelik denetimi yapılabilecektir. Kısaca belirtmek gerekirse; yerel yönetimler üzerinde uygulanan vesayet denetiminin özerklikle olan ilişkisi yerel yönetimlerin gerçek anlamda var olabilmesi için oldukça önemlidir. Bir sonraki bölümde, İtalyada belediyeler üzerindeki vesayet denetimi incelenecektir. 


\title{
Italya'da Belediye Yönetimlerin Denetimi
}

İtalya'da 1948 Cumhuriyet Anayasası’ndan önce yerel yönetimler üzerinde merkezi yönetimin kalıplaşmış yoğun baskıcı bir vesayet denetimi vardır. Cumhuriyet Anayasasının yürürlüğe girmesiyle birlikte Anayasa Mahkemesinin müdahaleleriyle yeni denetim organları olan özellikle yerel yetkililer, bölgesel izleme komiteleri (CORECO) ve siyasi organlar zamanla etkisini yitirmiştir. Yapılan bu çalışmalarla merkeziyetçi yaklaşım ve yerel yönetimlerin özerkliklerinin ağır vesayetle kısıtlanması durumu azaltılarak ortadan kaldırılmaya çalışılmıştır. Ancak merkezi yönetim, yerel yönetimlerin faaliyetlerini denetlemek, yaptığ1 işlemlerin meşruluğu ve yasal olduğunu tespit etmek gibi temel görevleri icra etmeye devam etmiştir. Bu durum kurumlarda, Anayasa’nın öngördügü fonksiyonellik, pratiklik ve tarafsızlık kriterlerinin gelişmesini engellememektedir (http://www.diritto.it/). Ancak üniter yapıya sahip olduğu için yerel yönetimlere tanıdı̆̆ı özerklik alanını genişletse bile onları çeşitli şekillerde denetlemektedir.

İtalya'da yerel yönetimlerin işlem ve eylemleri daha çok Anayasa ve diğer kanunlara uygunluk bakımından merkezi idarece veya onun adına oluşturulmuş komisyonlar aracılığıyla kontrol edilmektedir. Belediye yönetimleri geniş yetkileri olmasına karşın daha üst yönetimlerce denetlenmektedir.

İtalyada belediyelerin idari işlem ve eylemleri üzerindeki denetim, bölgesel bir organ olan bölge denetim komitesi tarafından yapılır. Bu komisyon; hukuk profesörleri, memurlar, hâkimler gibi uzmanlar arasından bölge meclisince seçilir. Komisyon, idari işlemlerin hukuka uygunluğu açısından denetim yapar. Sadece meclislerce alınan kararlar kontrole tabi tutulmaktadır. Yürütme organının kararları, yerel idare meclisinin, yürütme kurulunun veya meclis üyelerinde bir kısmının talebi üzerine denetime tabi tutulur. Meclis ya da encümen, kararları, yürürlük kazanabilmesi için hukukilik ve belediyenin yetki alanında olup olmadığı noktalarından incelemek üzere bölge yönetimini ildeki yetkilisinin incelenmesine sunar. Denetime tabi olan kararlar 20 gün içinde komite tarafından iptal edilmezlerse yürürlüğe girmiş sayılır (Ulusoy ve Akdemir, 2013, s.161). Bölge yönetimlerinin belediye kurma ve sınırlarını değiştirme yetkileri vardır. (Geray, 1997, s.61).

Ayrıca belediye meclisleri de feshedilebilir:

\begin{abstract}
"Belediye meclisi, Anayasaya aykırı işlemleri yapmaları, yasaları ciddi olarak ihlal etmeleri, ciddi bir kamu düzeni saikinin bulunması, yürütme kurullarını veya siyasi sorumluyu 60 gün içinde seçmemeleri halinde veya öngörülen sürede bütçeyi onaylamamaları halinde Cumhurbaşkanlığı kararnamesi ile fesih olunur. Metropol şehirlerde de benzer işlemler yapilı" (Tortop, 1996, s.70).
\end{abstract}

Fesih sonrasında yeni seçimlerin en kısa sürede yapılması gerekir ve bu süre içinde, belediyenin geçici yönetiminden sorumlu bir görevli atanmaktadır. İşlemez durumdaki belediye organlarının yerine vali de geçici olarak bir görevlendirme yapabilmektedir. 
Aynı şekilde Anayasaya aykırı işlemler yapan veya yasaları ısrarlı ve ciddi biçimde ihlal eden veya görevde bulunmalarında kamu düzeni nedeniyle ciddi sakıncalar bulunan belediye başkanı, yürütme kurulu başkan ve üyeleri de görevden alınabilir (Geray, 1997, s.61).

Valiler de olağanüstü suçlar işleyen belediye başkanı, meclis ve yürütme kurulu üyelerini görevden uzaklaştırabilirler (Ulusoy ve Akdemir, 2013, s.161). Bunun yanında belediye başkanı görevlerini yapmazsa, vali merkezi hükümet tarafından verilen görevleri (nüfus sayımı, seçmen kayıt listesinin hazırlanması, askere alım görevlerinin yürütülmesi, sertifikaların düzenlenmesi) yapmak üzere bir kimseyi atayabilmektedir (Ekici ve Toker, 2005, s.13).

İl sınırında değişiklik yapılmak ya da yeni iller kurulmak istendiğinde ise, 1948 İtalya Anayasası’nın 133.maddesine göre:

"İl sinırında değişiklikler ve bir bölge içinde yeni illerin kurulmasl, bölge ile görüşüldükten sonra, komünlerin girişimiyle, Cumhuriyet yasalarına göre düzenlenir.

Bölge, ilgili nüfus ile görüşüldükten sonra kendi sınırları içinde kendi yasaları ile yeni komünler kurabilir ve bunların mıntıka ve isimlerini değiştirebilir" (1948 İtalyan Anayasast, md.133).

İtalyan Anayasası'nın 133.maddesini incelediğimizde, bir bölge içinde illerin kurulması, il sınırında değişikliklerin yapılmak istenmesi durumunda önce bölge ile görüşülerek komünlerin de katılımıyla düzenleme yapılabilmektedir. Merkezi yönetimin yapılacak bu ilerin ayrıntısına müdahale etmediğini kararların yerel ve bölgesel birimlerin kendi sınırları içinde alındığını söylemek mümkündür. İl yönetimlerinin kararları üzerinde bölge yönetimlerinin ağırlıklı olarak yetkisi olduğunu görüyoruz.

\section{Türkiye'de Belediyelerin Denetimi}

Ülke yönetim bütünlüğü içinde yer alan, görev ve yetkileri, gelir kaynakları, yasama organı tarafından belirlenen yerel yönetimler, bağımsız siyasal kurumlar olmadığı gibi merkezi yönetimin hiyerarşik yapılanması içinde de değildir. Üniter yapı içinde ülke bütünlügünü sağlamak için yerel yönetimler denetime tabidir.

Yerel yönetimler üzerindeki merkezi yönetsel gözetim ve denetim yetkisinin kapsamına ilişkin genel kural Anayasa’nın 127. Maddesinde yer almaktadır. Bu maddede idari vesayet yetkisi şu şekilde ifade edilmektedir: "Merkezî idare, mahallî idareler üzerinde, mahallî hizmetlerin idarenin bütünlügü ilkesine uygun şekilde yürütülmesi, kamu görevlerinde birliğin sağlanması, toplum yararının korunması ve mahallî ihtiyaçların gereği gibi karşılanması amacıyla, kanunda belirtilen esas ve usuller dairesinde idarî vesayet yetkisine sahiptir”. Anayasanın bu maddesinden de anlaşılacağı gibi, mahalli hizmetlerin idarenin bütünlüğü ilkesine uygun bir şekilde yürütülmesi, kamu görevlerinde birliğin sağlanması, kamu yararının korunması ve mahalli ihtiyaçların gereği gibi karşılanması gibi amaçlar doğrultusunda idari vesayetin uygulanmasının önemi ve gerekliliği belirtilmiştir. Ancak 
burada dikkat çeken nokta vesayet denetiminin olması ya da olmaması değildir. Yerel yönetimlerin özerkliği için önemli olan konu, vesayet uygulamasının sınırlarıdır. Vesayet denetimi, yerindelik denetimi içermeyip hukuka uygunluk denetimiyle sınırlandırılmalıdır.

Belediyeler esas olarak iki şekilde denetlenir: İlki iç denetim dir ve bu denetim belediyelerin kendi örgütleri, birimleri, işlemleri ve hesapları üzerinde yapılan denetimdir. İç denetimi, belediyeler kendileri yaparlar. İkinci denetim ise, belediyeler üzerinde merkezi yönetimin yapmakta olduğu idari vesayet olarak isimlendirilen denetim türüdür. Keleş’e göre (1997), "asıl sorun kaynağı olan denetim türü ikinci denetimdir. Bunun nedeni, bu tür denetim, yerel siyasal ve toplumsal güçlerle merkezdeki siyasal güçler arasındaki bir erk paylaşımını doğrudan doğruya etkilemekte ve ondan etkilenmektedir" (Keleş, 1997, s.10). Bu etkileşim nedeniyle yerel yönetimler hem yerel siyaset hem de merkezi siyaset açısından önem taşımakta ve her iki taraf için de çıkarlar doğrultusunda yönlendirilmeye açık birimler olarak algılanabilmektedirler. Yerel yönetimler üzerinde uygulanan denetimin sınırlarının net bir şekilde belirlenmesi ve hukuki olarak yasal dayanak kazanması onların özerk hareket edebilmelerinde oldukça önemlidir.

Çünkü denetim ve özerklik kavramları ters orantılıdır. Denetim arttıkça özerkliğin alanı daralmaktadır. Bu nedenle merkezi yönetimin, yerel yönetimler üzerinde uyguladığ denetimin sınırları yerel yönetimlerin özerkliği açısından oldukça önemlidir.

Türkiyede vesayet denetimi, İçişleri Bakanlığı başta olmak üzere ilgili bakanlıklar tarafından yapılır. Vesayet denetimi genellikle hukuka uygunluk ve bazen de yerindelik bakımından yapılan bir denetim niteliğindedir. 5393 sayılı Belediye Kanunu da dış denetimin Sayıştay ve İçişleri Bakanlığı tarafından yapılacağı belirtilmektedir.

5393 sayılı Belediye Kanunu, belediye meclisi karalarının kesinleştiği tarihten itibaren yedi gün içinde mahallin en büyük mülki idare amirine gönderilmesi ve kesinleşen meclis kararlarının özetlerinin yedi gün içinde uygun araçlarla halka duyurulması öngörülmüştür. Mülki idare amirine gönderilmeyen kararlar yürürlüğe girmemektedir (5393 sayılı Belediye Kanunu, md. 23).

Belediye meclisi kararlarının onaya tabi olmaktan çıkarılmasının bir takım sonuçları vardır. Bunların en önemlileri, belediye bütçesi meclis kararıla kesinleştiğinden ve meclis kararları artık onaya tabi olmadığından belediye bütçesi üzerindeki mülki idare amirlerinin yetkileri ve personel istihdamı üzerinde merkezi idarenin (İçişleri Bakanlığı, Devlet Personel Başkanlığı, Maliye Bakanlığı, Bakanlar Kurulu) yetkileri ortadan kaldırılmıştır. Artık belediyelerin bütçe ve personel yapısı, doğrudan belediye meclisi, belediye encümeni ve belediye başkanı üçlüsü arasındaki işleyişle oluşacak, kesinleşecek ve uygulanacaktır (Ekici ve Toker, 2005, s.10).

Toprak’a göre; bu düzenlemede yerindelik denetiminin dışına çıkılarak, kararların yalnızca hukuka uygunluğunun "devletin ve hükümetin temsilcisi" olarak mülki amirler tarafından kontrolünü sağlamak olduğunun açıç̧a görüldüğünü ifade etmektedir. Meclislerin aldığı kararları, vali veya kaymakamların mahkemeye götürme yetkisini dolayısıyla vesayet yetkisini kaldırmıştır. Valinin mahkemeye başvurmasını önleyen kararın bir yıl sonra yürürlüğe gireceği hükme bağlanmıștır. Bir 
yıl içinde yasal düzenleme yapılmaması durumunda, belediye meclislerinde alınan kararlar üzerinde idarenin vesayet yetkisi bulunmayacaktır. Bu durum hukuki denetimi ortadan kaldıracağı için duruma "yerel özerklik" ilkesi üzerinden bakılmasını haklı çıkarmamaktadır. Yapılan değişikliğin, devletin sürdürülebilirliği ile birlikte değerlendirilmesi gerekir (Toprak, 2014, s.217).

Belediyelerin üzerindeki denetim ve kontrol için önemli olan bir noktada, Belediye Kanunu'nun 57.maddesinde; belediye hizmetlerinin ciddi bir şekilde aksatıldığı ve bu aksamanın halkın sağlık, huzur ve esenliğini hayati derecede olumsuz etkilediğinin, ilgili bakanlı̆̆ın talebi üzerine yetkili hukuk hakimince tespit edilmesi durumunda, İçişleri Bakanlığı aksatılan hizmetin özelliğine göre makul bir süre vererek aksamanın giderilmesini ilgili belediyeden isteyecektir Belediye meclisi, kendisine kanunla verilen görevleri süresi içinde yapmayı ihmal eder ve bu durum belediyeye ait işleri sekteye veya gecikmeye uğratırsa, belediyeye verilen görevlerle ilgisi olmayan siyasi konularda karar alırsa, İçişleri Bakanlığı’nın bildirimi üzerine Danıştay kararı ile feshedilir. Verilen bu süreye rağmen herhangi bir olumlu gelişme sağlanamadığ 1 takdirde Bakanlık, belediyenin bulunduğu ilin valisini görevlendirerek aksayan hizmetin görülmesini isteyecek, vali öncelikle belediyenin ve ihtiyaca göre diğer kamu kurum ve kuruluşlarının olanaklarını kullanarak aksamayı ortadan kaldıracaktır (5393 sayılı Belediye Kanunu, md. 57).

- Belediye Kanunu'nun 30.maddesinde belediye meclisinin feshi ile ilgili gerekçeler şu şekildedir: Kendisine kanunla verilen görevleri süresi içinde yapmayı ihmal eder ve bu durum belediyeye ait işleri sekteye veya gecikmeye uğratırsa,

- Belediyeye verilen görevlerle ilgisi olmayan siyasî konularda karar alırsa, İçişleri Bakanlığının bildirimi üzerine Danıştayın kararı ile feshedilir. İçişleri Bakanlığı gerekli gördüğü takdirde meclisin feshine dair bildirim ile birlikte, karar verilinceye kadar meclis toplantılarının ertelenmesini de ister. Danıştay, bu hususu en geç bir ay içinde karara bağlar. Bu şekilde feshedilen meclisin yerine seçilen meclis, kalan süreyi tamamlar (5393 sayılı Belediye Kanunu, md.30).

Siyasi bir kurum olan belediyelerin karar organları içerisinde siyasi konuların tartışılmasının yasaklanması kurumun varlığına ters düşen bir durumdur. Yasada belirtilmek istenen partizanca davranışları engellemek ve bu durumun önüne geçmektir.

Belediye hizmetlerinin yerine getirilmemesi halinde meydana gelen aksamaların kamu güvenliğini olumsuz yönde etkilemesi durumunda vesayet mekanizması işlemektedir. İçişleri Bakanı, belediye başkanına makul bir süre vererek meydana gelen aksaklıkların giderilmesini talep eder. Belediye personelleri de belediye başkanının ataması ile göreve gelir.

\section{İdari Vesayet Denetimi Açısından İtalya ve Türkiye'de Belediyelerin Karşılaştırılması}

Üniter yönetim yapısına sahip olan İtalya ve Türkiye'de yönetsel açıdan, merkezi idarenin yerel yönetimler üzerindeki idari vesayet yetkisinin kabul edildiğini söylemek mümkündür. 
İtalya'da belediyelerin denetimi Anayasa ve diğer kanunlara uygunluk bakımından merkezi yönetim ya da merkezi yönetim adına oluşturulmuş komisyonlar aracılığıyla yapılmaktadır. Belediyelerin idari işlem ve eylemleri bölgesel bir organ olan bölge denetim komitesi tarafından yapılmaktadir.

Üniter devlet yapısına sahip olmasına karşın İtalya’nın yerel yönetim sistemi Türkiye’den farklı olarak bölgesel yönetimlere de yer vermektedir. İtalya yerel ve bölgesel olarak dört yönetim kademesine sahiptir. Kademe olarak ele aldığımızda bölgeler belediye yönetimlerinin üstündedir (İtalyan Anayasası, md. 114). Türkiye'deki belediye yönetimleriyle karşılaştırıldğında İtalya'daki belediyeler daha geniş yetkilere sahiptir. Türkiye'de merkezi idare tarafından yapılan idari vesayet denetimi İtalya’da bölge yönetimleri tarafından yapılmaktadır.

Bölge denetim komitesinin; hukuk profesörleri, memurlar, hâkimler gibi uzmanlar arasından seçilen kişilerden oluşturulması yapılacak olan denetimin niteliği açısından oldukça büyük önem taşımaktadır. Türkiye’ye kıyasla daha geniş ve kalifiye yelpazeden seçilerek oluşturulan bu komite belediyelerin idari işlemlerini hukuka uygunluk açısından denetler ve bu denetim Avrupa Yerel Yönetimler Özerklik Şartı’nın 8.maddesinde belirttiği denetim şekline uygunluk gösterdiği söylenebilir.

İtalyada belediyenin yürütme organının aldığı kararlar, yürütme kurulunun veya meclis üyelerinin bir kısmının ve yerel idare meclisinin talebi üzerine denetime tabi tutulur. Türkiyede ise belediyeler üzerinde merkezi yönetimin bakanlıkları tarafından denetim yapılmaktadır. İtalyadan farklı olarak ise belediyeler, hukukilik denetiminin yanında yerindelik denetimine de tabi tutulmaktadır. Ancak yapılan değişiklik sonucunda; belediye meclisinde alınan kararların mülki idare amiri tarafından onaylanmasına son verilmiştir. Bunun anlamı, belediye meclisi kararları üzerindeki vesayet denetiminin kaldırılmasıdır.

Belediye meclisi kendisine kanunla verilen görevleri süresi içinde yapmayı ihmal eder ve bu durum belediyeye ait işleri sekteye veya gecikmeye uğratırsa, belediyeye verilen görevlerle ilgisi olmayan siyasi konularda karar alırsa, İçişleri Bakanlığı’nın bildirimi üzerine Danıştay kararı ile feshedilir. İtalya'da belediye meclisi, Anayasaya aykırı işlemler yapmaları, yasaları ciddi olarak ihlal etmeleri, ciddi bir şekilde kamu düzeni saikinin bulunması, yürütme kurullarını veya siyasi sorumluyu 60 gün içinde seçmemeleri halinde veya öngörülen sürede bütçeyi onaylamamaları halinde Cumhurbaşkanlığı kararnamesi ile fesih olunur.

Belediye meclisin feshedilmesi durumunda meclis çalışamaz duruma gelirse, çalışabilir duruma gelinceye kadar veya yeni meclis seçimi yapılıncaya kadar meclis görevi, belediye encümeninin memur üyeleri tarafından yürütülür. İtalya'da meclisin feshedilmesi durumunda yönetimden sorumlu bir görevli atanmaktadır. Belediye organlarının işlemez hale gelmesi durumunda, vali bu organların yerine geçici olarak bir görevlendirme yapabilmektedir. Belediye meclisinin feshi durumunda Türkiye’de ve İtalya'daki meclisin yerine yapılan görevlendirmeler benzerlik göstermektedir. 
Belediye başkanının mazeretsiz ve kesintisiz olarak 20 günden fazla görevini terk etmesi ve bu durumun mahallin mülki idare amiri tarafından belirlenmesi, seçilme yeterliliğini kaybetmesi, görevini sürdürmesine engel bir hastalık veya engellilik durumunun yetkili sağlık kuruluşu raporuyla belgelenmesi ve meclisin feshine neden olan eylem ve işlemlere katılması hallerinden birinin meydana gelmesi durumunda İçişleri Bakanlığının başvurusu üzerine Danıştay kararıyla başkanlık sıfatı sona erer. İtalya'da anayasaya aykırı işlemler yapan veya yasaları ısrarlı ve ciddi bir şekilde ihlal eden veya görevde bulunmamalarında kamu düzeni nedeniyle ciddi sakıncalar bulunan belediye başkanı, yürütme kurulu başkan ve üyeleri görevden alınır. Belediye başkanı görevlerini yapmazsa, vali merkezi hükümet tarafından verilen görevleri yapmak üzere bir kimseyi atayabilmektedir. İtalya’da belediye başkanının görevden alınmasının nedenleri arasında anayasaya aykrılık içeren durumlar gösterilmesine karşın Türkiyede görevini mazeretsiz terk etme gibi önemi daha az olan nedenler gösterilerek görevine son verilmektedir. İtalyała belediye başkanının görevden alınması Türkiye’ye göre daha ciddi ve önemli nedenlerle olmaktadır. $\mathrm{Bu}$ noktada Türkiyede belediyeler üzerindeki denetimin daha yoğun bir şekilde uygulandı̆̆ı ve belirgin olmayan vesayet sınırları içerisinde kolay müdahale imkânının bulunduğu, İtalyada ise denetim mekanizmasının sınırlarının daha keskin ve net olduğu bu sebeple AYYÖş ilkelerine daha uygun hareket ettiği söylenebilir.

Fesih ve görevin sona ermesinde Türkiye'de yargı kararları/güvencesi varken ve kriterler somut olarak belirlenmiş iken, İtalya’da bu iş idari kararla olabilmektedir. Bu açıdan uygulama sürecindeki sorunlardan bağımsız olarak Türkiye’nin yasal durumunun İtalyadan daha iyi olduğu söylenebilir.

İtalya ve Türkiye'nin belediye yönetimleri karşılaştırıldığında vesayet denetiminin Türkiye'de daha ağır uygulandığını İtalya’da ise özerkliğe ve yerel yönetim birimlerine verilen önemden dolayı vesayet denetiminin sınırlarının AYYÖŞ’e uygunluk gösterdiğini söyleyebiliriz.

\section{Sonuç}

Yerel yönetimler, yerel özerkliğin varlı̆̆ 1 açısından oldukça önemli bir yere sahiptir. Yerel yönetimlerin özerkliği, kanunlarla belirlenen sınırlar çerçevesinde, kamu işlerinin önemli bir bölümü kendi sorumlulukları altında ve yerel nüfusun çıkarları doğrultusunda düzenleme ve yönetme hakkı ve imkânı anlamını taşımaktadır. Yerel yönetimlerin kendi organlarıyla kendileri ile ilgili konularda merkezin baskısı ve yönlendirmesi olmadan kendi imkânlarıyla karar alabilmesi özerklik için büyük önem taşımaktadır.

Merkezi yönetim yerel yönetimler üzerindeki vesayet denetimini arttırırsa yerel yönetimlerin özerkliğini kısıtlamış olur ve yerel yönetimler gerçek varlığını yitirir. Sonuç olarak da merkezi yönetimin hiyerarşik birimlerinden pek de farkı kalmaz. Bu nedenle özerklik yerel yönetimlerin gerçek anlamda var olabilmesi için büyük önem arz etmektedir. 
Makalede ele alınan İtalya ve Türkiye’nin Avrupa Yerel Yönetimler Özerklik Şartı bağlamında denetime olan yaklaşımları incelendiğinde Türkiye'nin uyguladı̆̆ı denetimin İtalyàya kıyasla Şarta pek de uygun olduğunu söylemek mümkün değildir.

Avrupa Yerel Yönetimler Özerklik Şartı 8.maddesinde yerel yönetimlerin denetimine yer vermiştir.

Özerklik şartı prensip olarak, idari vesayeti, hukuka uygunluk denetimiyle sınırlandırmıştır. İtalya Şart'ın 8.maddesini onaylarken Türkiye bu maddeye çekince koymuştur. Türkiye bu maddeye çekince koymasına rağmen 5393 sayılı Belediye Kanunu ile yaptığı değişiklikle belediyeler üzerindeki yoğun vesayet denetimini kaldırdığını söylemek mümkündür. Ancak daha sonra yapılan düzenlemeler ile yerel yönetimler üzerindeki yoğun idari vesayet denetimini devam ettirmiştir.

İtalya üniter yapılı bir devlet olmasına rağmen bölgeselleşmeye doğru giden bir yol izlemektedir. Ülkedeki kuzey-güney ayrımı, bölgesel farklılıklar nedeniyle bölgesel yönetimlere önem verilmekte ve yerel ve bölgesel yönetimlerin özerkliklerini arttırma eğilimine gitmektedirler. Merkezi yönetim bölgesel yönetimleri yoğun bir şekilde denetlememektedir. Bölgesel yönetim ise, illeri ve belediyeleri hukuki açıdan denetlemektedir. İtalya’nın izlediği bölgeselleşme politikalarını ele aldığımızda Şart’ın bu maddesini onaylaması oldukça tutarlı görünmektedir. Yerel ve bölgesel yönetimlerinin özerkliğini Anayasal olarak koruyan İtalya yaptığı reformlarla yerel yönetim birimlerinin özerkliklerini daha da genişletme yoluna gitmektedir.

Türkiye ise üniter yapıya sahip bir ülke olarak, 2000’li yıllardaki yerel yönetim reformlarına rağmen merkeziyetçi niteliğini sürdürmektedir.

Yerel yönetimler üzerinde vesayet denetiminin yoğun olması, yerel yönetimlerin demokratik niteliğine zarar verir ve işlevlerini yapabilmelerine mani olur. Bu nedenle merkezi yönetim ve yerel yönetim arasındaki ilişkinin sınırları ve bu sınırların yasalarla belirlenmiş olması oldukça önemlidir. Vesayet denetiminin sınırlarının çizilmesi ve yerel yönetimlerin varlığının yasalarla güvence altına alınması onların özerk hareket edebilmeleri açısından önemlidir.

İtalya ve Türkiye yerel yönetimlerin özerkliği noktasında yukarıda bahsedildiği üzere birbirinden farklılık göstermektedir. İtalya’nın yerel yönetimler üzerindeki denetim sınırları ve Avrupa Yerel Yönetimler Özerklik Şartı’na bakış açısı bağlamında Türkiye’ye örnek olabilecek özellikler barındırdığı söylenebilir. 


\section{Kaynakça}

Açıkgöz, E. (2007), "Yeni Düzenlemeler Eşliğinde Yerel Yönetimlerde Mali Özerklik ve Mali Tevzin”, (Yayınlanmamış Yüksek Lisans Tezi), Süleyman Demirel Üniversitesi SBE, Isparta.

Aktalay, A. (2010), "Yeni Kamu Yönetimi Anlayışı Çerçevesinde Merkezden Yönetim ve Yerinden Yönetim Arasındaki Denetim İlişkisi“, (Yayınlanmamış Doktora Tezi), Dokuz Eylül Üniversitesi Sosyal Bilimler Enstitüsü, İzmir.

Arıkan, Y. E. (2004), Bütünleşen Avrupa'da Yerel Yönetimler, Görüş, TÜSİAD Yayınları, İstanbul.

Avrupa Yerel Yönetimler Özerklik Şartı, http://www.tbb.gov.tr/mevzuat/kanunlar/Avrupa_Yerel_

Yonetimler_ozerklik_Sarti.pdf [Erişim Tarihi: 10.05.2016].

Can, B. (2013), "Belediye Hizmetlerinin Yerine Getirilmesinde Öncelik Sirası Sorunu”, EÜHFD, C. XVII, S.1-2, ss. 177-199.

Coşkun, B. (1996), “Türkiye’de İdari Vesayet Denetimi ve Yerel Yönetimlerin Özerkliği” Çağdaş Yerel Yönetimler Dergisi, Cilt 5, Say1 3, s.35-47.

Çam A. Ç. (2012) "Yerelleşme, Yerel İktidar ve Yerel Demokrasi”, (Yayınlanmamış Doktora Tezi), Marmara Üniversitesi, Sosyal Bilimler Enstitüsü.

Çelik, V. \& Çelik, F. ve Usta S. (2008), Yerel Demokrasi ve Yerel Özerklik İlişkisi, Niğde Üniversitesi İİBF Dergisi, Aralık 2008, Cilt 1, S. 2, ss. 87-104.

Çukurçayır, M. A. (2013), Yerel Yönetimler Kuram, Kurum ve Yeni Yaklaşımlar, Çizgi Kitabevi, 2. Baskı, Konya.

Dente, B. (1991), Italian Local Services The Difficult Road Towards Privatisation, Richard Batley and Gerry Stoker (Ed.), Local Government in Europe Trends and Developments, Macmillan Press, London.

Dursun, H. (2007), "Belediye Dizgesine Getirilen Yeniliklere Genel Bir Bakış”, TBB Dergisi, Sayı 70, ss. 359426.

Ekici, .l ve Toker, M. C. (2005), “Avrupa'da ve Ülkemizde Yerel Yönetimlerin Denetimi ve Etkinliği”, Çağdaş Yerel Yönetimler Dergisi, Cilt 14, Say1 1, 1 Ocak 2005, s.5-28.

Egeli H. ve Diril F. (2012), “Türkiyede Yerel Yönetimlerde Mali Özerklik ve Vergilendirme Yetkisi”, Sayıștay Dergisi, S. 84, 25-44.

Eryılmaz, B. (2010), Kamu Yönetimi, Okutman Yayıncılık, 3. Baskı, Ankara.

Eryılmaz, B. (2015), Kamu Yönetimi, Umuttepe Yayınları, 8. Baskı, Kocaeli.

Geray, C. (1997), "Ülke Ülke Yerel Yönetimler: İtalya’da Yerel Yönetimler”, Çağdaş Yerel Yönetimler Dergisi, Cilt 6, Sayı 1, Ocak 1997, ss. 53-76.

Gözübüyük, Ş. (1971), Türkiye’nin İdari Yapısı, TODAİE Yayınları, 2. Baskı, Ankara.

Hine, D. (1993), Governing Italy: The Politics of Bargained Pluralism, Clarendon Press Oxford, United States. İtalya Cumhuriyeti Anayasası, http://www.adalet.gov.tr/, (10/12/2015).

Karabaş, E. (1991), “Avrupa Topluluğu Ülkelerinde Yerel ve Bölgesel Yönetimlerin Yapısı”, (Yayınlanmamış Doktora Tezi), İstanbul Üniversitesi/ Sosyal Bilimler Enstitüsü, İstanbul.

Keleş R. (1997), “Yerel Yönetimlerde Denetim”, Sayıştay Dergisi, Özel Sayı 25, Nisan-Haziran 1997.

Keleş, R. (2012), Yerinden Yönetim ve Siyaset, Cem Yayınevi, 8. Baskı, İstanbul.

Koçak, H. (1996), “Ülke Ülke Yerel Yönetimler: İtalya’da Yerel Yönetimler”, Çağdaş Yerel Yönetimler Dergisi, Cilt 5, Sayı 4, Temmuz 1996, ss. 57-66.

Koşar, N. (2013), “İtalya’da Yerel Yönetimler ve Merkezi Yönetim-Yerel Yönetimler Arası Mali İlişkiler”, Uluslararası Yönetim İktisat ve İşletme Dergisi, Cilt 9, Sayı 18.

Loughlin, J. (2001), Subnational Democracy in the European Union, Oxford University Press, United States. 
Mengi, A. (2007), Avrupa Birliği’ne Uyum Sürecinde Yerel Yönetimlerle İlgili Düzenlemeler, Ayşegül Mengi (Ed.), Yerellik ve Politika Küreselleşme Sürecinde Yerel Demokrasi, İmge Kitabevi, Ankara.

Nalbant, A. (1996), "Bölgesel Devlet Yeni Bir Devlet Biçimi Mi? (II) Uygulama: İtalya Ve İspanya Örnekleri”, Amme İdaresi Dergisi, Cilt 29, Sayı 3, Eylül 1996.

Nalbant, A. (2012), Üniter Devlet, XII Levha Yayınları, 2. Baskı, İstanbul.

Onar, S. S. (1966), İdare Hukukunun Umumi Esasları, Cilt: I-II, 3. Baskı, İstanbul.

Ökmen, M. ve Parlak, B. (2013), Kuram ve Uygulamada Yerel Yönetimler, Orion Kitabevi, 3. Baskı, Ankara.

Sanal, R. (2008), "Yeni Yasal Düzenlemelerin Işı̆̆ında Yerel Yönetimlerin Denetimi“, Türk İdare Dergisi, Say1.458, ss. 101-128.

Selçuk, H. (2014), "Yerel Yönetimler ve İdari Vesayet" (Yayınlanmamış Yüksek Lisans Tezi), Atatürk Üniversitesi/Sosyal Bilimler Enstitüsü, Erzurum.

Sobac1, M. Z. (2015), “Türkiye’nin Avrupa Yerel Yönetimler Özerklik Şartı’na Uyumu Özerklik Miti”, SETA, Nisan 2015, Sayı 120

Şensoy, B. (2010), "Yerel Özerklik ve Yerel Yönetimler Üzerindeki İdari Vesayet" (Yayınlanmamış Doktora Tezi), Marmara Üniversitesi / Sosyal Bilimler Enstitüsü, İstanbul.

Toksöz, F. ve diğerleri, (2009), Yerel Yönetim Sistemleri, TESEV Yayınları, İstanbul.

Toprak, Z. (2014), Yerel Yönetimler, Siyasal Kitabevi, 9. Baskı, İzmir.

Tortop, N. (1996), “Ülke Ülke Yerel Yönetimler: İtalyảda Yerel Yönetimlerin Yapısı ve Son Düzenlemeler”, Çağdaş Yerel Yönetimler Dergisi, Cilt 5, Sayı 3, Mayıs 1996, ss.63-70.

Türkiye Cumhuriyeti Anayasası, https://www.tbmm.gov.tr/anayasa/anayasa82.htm, (05/11/2015).

Türkyılmaz, A. (2014), "Belediyelerde Denetim“ Kidder (Kamu İç Denetçiler Derneği) Denetişim 2014-2015, ss. 16-33.

Ulusoy, A. ve Akdemir, T. (2013), Mahalli İdareler, Seçkin Yayınevi, 8. Baskı, Ankara.

Uygun, O. (2015), "Yerel Yönetim Reformu için Anayasal İlkeler", Marmara Üniversitesi Stratejik Kamu Yönetimi Sempozyumu’nda sunulan bildiri metni, ss.1-18.

Ünal, F. (2013), Türkiye’de Yerel Yönetimlerin Denetimi ve Yerel Yönetim Ombudsmanı, Savaş Yayınevi, Ankara.

5393 Sayılı Belediye Yasası, 13.07.2005 Tarih ve 25874 sayılı Resmi Gazete.

5018 Sayılı Kamu Mali Yönetimi Ve Kontrolü Yasası, 24.12.2003 Tarih ve 25326 sayılı Resmi Gazete.

fundatore Francesco Brugaletta, http://www.diritto.it, (Erişim Tarihi:12.10.2017).

Funzioni e competenze del Consiglio Comunale, http://www.comunedisoglianocavour.gov.it/consiglio/376funzioni-e-competenze-del-consiglio-comunale, (Erişim Tarihi: 28.11.2017). 